\title{
JIA affected sibling pairs present high correlation for ANA and ILAR category
}

\author{
G Filocamo*, C Malattia, I Foeldvari, V Stanevicha, S Nielsen, T Herlin, C Pruunsild, F Zulian, Z Balogh, F Dressler, \\ I Rumba, MG Alpigiani, E Cortis, F Falcini, R Trauzeddel, G Calcagno, L Lepore, M Alessio, DN Glass, SD Thompson, \\ A Martini, N Ruperto, for the Paediatric Rheumatology International Trials Organisation (PRINTO)
}

From 18th Pediatric Rheumatology European Society (PReS) Congress

Bruges, Belgium. 14-18 September 2011

\section{Aims}

1)To investigate the clinical phenotypes and demographic characteristics of affected sibling pairs (ASPs) with juvenile idiopathic arthritis (JIA)

2)To provide an international resource of JIA DNA samples and a base of knowledge from which all genes contributing to the pathogenesis of JIA can be identified.

\section{Methods}

This is a cross-sectional multicentric study in which all paediatric rheumatology centres belonging to the

Table 1

\begin{tabular}{|c|c|c|c|c|c|c|}
\hline & N (\%) & $\begin{array}{l}\text { Mean } \\
\text { (SD) }\end{array}$ & Median & Min & Max & Conc. \\
\hline $\begin{array}{l}\text { Male } \\
\text { Female }\end{array}$ & $\begin{array}{l}25(24) \\
81(76)\end{array}$ & & & & & $\begin{array}{l}0.24 \\
0.79\end{array}$ \\
\hline Onset age -years & & $6.6(4.4)$ & 6.2 & 0.5 & 16.3 & \\
\hline $\begin{array}{l}\text { JIA category } \\
\text { Systemic arthritis } \\
\text { Oligoarthritis persistent } \\
\text { Oligoarthritis extended } \\
\text { Polyarthritis RF } \\
\text { negative } \\
\text { Polyarthritis RF positive } \\
\text { Psoriatic arthritis } \\
\text { Enthesitis related } \\
\text { arthritis } \\
\text { Other }\end{array}$ & $\begin{array}{l}0(0) \\
61 \\
(57.6) \\
18(17) \\
21 \\
(19.8) \\
2(1.9) \\
3(2.8) \\
0(0) \\
1(0.9)\end{array}$ & & & & & $\begin{array}{l}0.79 \\
\\
0.85 \\
0.5 \\
0.9 \\
1 \\
0.67 \\
0\end{array}$ \\
\hline $\begin{array}{l}\text { Presence of ANA } \\
\text { Absence of ANA }\end{array}$ & $\begin{array}{l}56(56) \\
44(44)\end{array}$ & & & & & $\begin{array}{l}0.78 \\
0.68\end{array}$ \\
\hline $\begin{array}{l}\text { Presence of iritis } \\
\text { Absence of iritis }\end{array}$ & $\begin{array}{l}11(10) \\
86(81)\end{array}$ & & & & & $\begin{array}{l}0.36 \\
0.9\end{array}$ \\
\hline
\end{tabular}

PRINTO network were asked to participate. PRINTO asked to provide demographic and clinical characteristics of the ASPs through electronic format and to collect DNA samples of JIA familiar cases, including all first degree relatives, deriving from the different centres.

\section{Results}

Table 1. Demographic, clinical features and concordance between the sibs ( 2 or more within the same family) of the 106 individual affected sibpairs with JIA

\section{Conclusion}

Preliminary results confirm the findings of earlier studies showing familial aggregation of clinical features among ASPs. In our study we observed high concordance of the presence of antinuclear antibodies (ANA), providing evidence for a genetic background in this disease. The DNA samples collected will allow to develop future studies on JIA.

Published: 14 September 2011

doi:10.1186/1546-0096-9-S1-P193

Cite this article as: Filocamo et al:: JIA affected sibling pairs present

high correlation for ANA and ILAR category. Pediatric Rheumatology 2011 9(Suppl 1):P193.

\footnotetext{
*Correspondence: giovanni.filocamo@gmail.com

IRCCS G. Gaslini, Pediatria II, PRINTO, Italy

Full list of author information is available at the end of the article
}

C Biomed Central

(C) 2011 Filocamo et al; licensee BioMed Central Ltd. This is an open access article distributed under the terms of the Creative Commons Attribution License (http://creativecommons.org/licenses/by/2.0), which permits unrestricted use, distribution, and reproduction in any medium, provided the original work is properly cited. 